Max-Planck-Institut für demografische Forschung

Max Planck Institute for Demographic Research

Konrad-Zuse-Strasse $1 \cdot$ D-18057 Rostock · GERMANY

Tel +49 (0) 3812081 - 0; Fax +49 (0) 3812081 - 202;

http://www.demogr.mpg.de

MPIDR WORKING PAPER WP 2008-001

JANUARY 2008

\title{
Family Reunification Ideals and the \\ Practice of Transnational Reproductive \\ Life among Africans in Europe
}

Caroline H. Bledsoe

Papa Sow

This working paper has been approved for release by: Hill Kulu (kulu@demogr.mpg.de)

Deputy Head of the Laboratory of Contemporary European Fertility and Family Dynamics.

(C) Copyright is held by the authors.

Working papers of the Max Planck Institute for Demographic Research receive only limited review. Views or opinions expressed in working papers are attributable to the authors and do not necessarily reflect those of the Institute. 


\title{
Family Reunification Ideals and the Practice of Transnational Reproductive Life among Africans in Europe ${ }^{1}$
}

\author{
Caroline H. Bledsoe \\ Department of Anthropology \\ Northwestern University \\ Evanston, Illinois 60208 \\ Papa Sow \\ Grup de Recerca sobre Migracions \\ Department of Geography \\ Universitat Autònoma de Barcelona \\ Spain
}

Acknowledgements: This project was funded by the Max Planck Institute for Demographic Research in Rostock, Germany. We are indebted to many individuals whose insights as well as generosities of time and engaged critique have been pivotal. Among them have been Gunnar Andersson, Yussuf Badji, Pau Baizan, Laura Bernardi, Adama Bojang, Jalika Bojang, Anna Cabré, Eva Cham, Jennifer Cole, Bully Diawara, Nuria Empez, Albert Ficat, Annett Fleischer, Jan Hoem, Jalika Jam, Anna Jeremies, Jennifer JohnsonHanks, René Houle, Hill Kulu, Adriana Kaplan Marcusán, Boury Marianne Rosalie Mendy, Ferran Moreno, Vicens Galea Montero, Gerda Neyer, Merixtell Pérez, Dan Rodríguez García, Augustin Senghor, Mohamad Saybo Silla, Alassane Silla, Montse Solsona, Andres Vikat, Josep Vilarmau, and Ana M. Zaragoza Bas. Special thanks to Alaina Dyne for bibliography work.

1 Forthcoming in Globalization, Reproduction and the State, edited by Carole Browner and Carolyn Sargent. Duke University Press. 


\section{Introduction}

In the European Union, as in much of the industrialized world, family life is quietly becoming the major battleground of immigration struggles. It is doing so through the logics generated by family reunification, now a key mode of legal entry into Europe. International law defines family reunification as the joining of previously separated, or newly acquired, ties who society defines as a family. Building on the rich and growing scholarly corpus on global flows of technologies, good, and people, this paper turns to the spread of global humanitarian conventions, the domain under which family reunification usually falls, and their impact on local immigration practices for African reproductive life in Europe. We look through the lenses of recent anthropological interests in reproduction and transnationalism to suggest that family reunification doctrine, like any ideological system, can produce perverse effects; all depends on the context and the agenda. In this case, however, the irony is particularly sharp: Despite humanitarian claims to protect the family as the moral core of human relations, the same measures that were designed to bring families together can divide them along precisely the same fault lines they sought to address. To unravel the conditions that can give rise to the opposite effects from those intended by their drafters, we assemble three theoretical strands -- partibility, commoditization, and a notion of social agency we call "acts of selection" to consider the dynamics that arise from allowable family reunification categories of marriage and parent-child relations. We argue as follows:

Family reunification doctrine builds on the concept of a person as a collection of single characteristics, some of which can be converted to transactable immigration value, but only under two conditions: this value must be defined with respect to another person, and it can only be converted across a national boundary. Moreover, the rules governing each position differ, so each position implicitly orients to a separate pathway of legal mobility; all, however, turn on a common binary feature of quantity. Positions such as that of "children" operate on the principle of plurality; that is, they can be held by more than one person at a time. The position of "spouse" is singular, effectively a "slot": it can be held by just one person at a time. Multiple people, however, can circulate through it over time. To the extent that its overall agenda is to include, we believe, the state is likely to take a benign approach to the actual practices that surround family reunification positions. Under political pressures to exclude, however, it may deploy more systematic regulatory scrutiny over immigrants' family reunification efforts by demanding tight compliance with the separate logics of relationship, age, and quantity that underlie each position. The outcome may be new, if not distorted, versions of family life, whether by comparison to the home country or the country of immigration. For citizens of poor countries, particularly those that do not belong to the OECD,2 social relationships and even age itself can become commoditized objects of barter and commerce as people try to shape their lives to accommodate a narrowing set of entry demands. Immigrants' themselves, in fact, may feed the potentials for distortion structured by state policies by selecting those family members for reunification whose attributes will most likely pass immigration muster.

To illustrate these points, we examine several brief case studies, most emerging from a recent collaborative project3 that focused on African groups in Europe: Moroccan youth in Spain (Empez),

2 The Organisation for Economic Co-operation and Development (www.oecd.org), a collection of 30 prosperous countries, mostly European but including others such as the U.S., Korea, Australia, Turkey, and Mexico, with countries such as Estonia, Chile, and Russia currently being considered for membership.

3 This 2004-2007 project, entitled “Transnational Vital Events," was sponsored by the Max Planck Institute for Demographic Research, in Rostock, Germany. Building on our collective previous experience in Africa and Europe, the research contained a various mix of ethnography and demography. The ethnographic fieldwork was conducted in Spain, 
Cameroonian men and women in Germany (Fleischer), and Gambian families in Spain (Bledsoe, Houle, Sow). In Germany, the post-war period in which the nation needed outside labor (the "gastarbeiter," or "guestworker," period, from the 1950's to the 1970's) has long since ended, and the country has so tightened its labor market that non-residents without highly sought technical skills have little chance of staying. The few Africans who now try to come to Germany are often highly educated, coming for advanced training or on jobs for highly technical skills; others come on asylum claims, almost none of which are now granted. Spain's immigration situation relative to Africa is entirely different. Not only is the country far more accessible geographically to Africa than Germany, but the country needs low skilled labor, and it has now overtaken France as the leading European host country, proportionate to its national population, for immigrant arrivals. 4 The country, however, embodies sharp migration dilemmas by virtue of its geography and economy. Situated at the edge of the EU, with vast tracts of borderland exposed to the external world and an economy heavily reliant on agriculture and construction, this "interface" country is caught between pressure from its European neighbors to tighten its borders and the risk of excluding the labor needed to maintain its economy.

The challenges faced by these three groups- two from the same country, the other from a country with a very different immigrant context -- reveal complementary facets of the logics generated by characteristics of age, marriage and parenthood. After describing the historical background of family reunification policies and the basal logics that underlie the family positions of spouse and child, we examine social practices based on ideologies on the rights of the child and family reunification that shape forms of immigrant life in these places.

\section{$\underline{\text { Background }}$}

As a topic in the age of transnationalism, $\mathbf{5}$ the attempt to conduct life across more than one national context, reproduction has drawn surprisingly little explicit attention in anthropology or sociology.6 In demography, the topic has tended to take the form of debates over whether immigrants' youthful age pyramids might help solve the economic and care crises posed by a rapidly aging Europe (e.g., United Nations, 2000; Coleman and Rowthorn, 2004). Most research has concluded that on the whole, this will not happen. Fertility levels across much of the world are falling rapidly, and most immigrants quickly adopt the fertility levels of their host countries (Kulu, 2005). For immigrants themselves, especially those from poor countries, concerns about reproductive life are very different. One concern is the physical risk that reproduction entails. Birth remains an event of potentially mortal consequence for mother and child, and childbearing women in states where they are not recognized as legal residents can drop below the horizon of national health care.7 Conducting a transnational existence means that a state to which a person does not belong can set the terms by which his or her reproductive life must transpire.

Morocco, Germany, and Cameroon; the main demographic data came from the extensive national surveys and censuses as well as vital registries from a number of countries that are available to the Max Planck Institute.

4 http://yaleglobal.yale.edu/article.print?id $=5702$.

5 For in-depth discussions, see, for example, Glick-Schiller et al. (1995), Hannerz (1996), Ong (2002), Levitt (2001), Vertovec (2001), Levitt \& Glick Schiller (2004), and Dahinden (2005).

6 For recent works in anthropology and sociology, however, see Ginsburg and Rapp (1995), Hondagneu-Sotelo (1995, 2002), Hochschild (2000), Inda (2002), Cole and Durham et al. (2006); and this volume.

7 http://www.lakareutangranser.se/files/ReportGomdaSwedenEn.pdf 
While Schengen rules allow EU citizens to travel internally without either visas or passport control and Americans tourists can enter Europe with a passport, citizens of "high migration potential" countries may be required to obtain expensive visas and undergo intensive scrutiny.8 Family members may no longer be allowed to live together or travel, making them reluctant to travel at all, lest they be denied re-entry. What is more, rules of belonging may change specifically to disrupt the pathways that marginal newcomers have tried to stitch together to conduct a coherent life. Shifts in national rules of movement undermine any degree of predictability for conducting an intensively invested reproductive sequence.9

\section{The legal architecture of family reunification}

The twentieth century has seen the genesis of an enormous body of international law bearing on human rights. Among the most important measures shaping current family reunification doctrine was the 1990 International Convention on the Protection of Rights of Migrant Workers,10 though it has been accepted largely by "sending" nations. Important as well was the 1989 UN Convention on the Rights of the Child,11 now adopted by all countries except the United States and Somalia. The most basic tenet of the human rights corpus is that all people, irrespective of citizenship, ethnicity, religion, or gender, have certain basic entitlements simply because they are human beings. Following World War I, calls for such measures were among the principal inspirations for the League of Nations. In the late 1940's, following World War II, the United Nations Charter sought "respect for human rights and for fundamental freedoms for all without distinction as to race, sex, language or religion" (Art. 1, para. 3). And the UN's Economic and Social Council charged its new Commission on Human Rights to draft an "International Bill of Human Rights."12 This bill urged governments "to provide for all human beings a life consonant with freedom and dignity and conducive to physical, mental, social and spiritual welfare." It advocated, among other things, freedom from torture, slavery, and arbitrary arrest; the right to a fair and public trial; freedom of movement, expression, and peaceful assembly; and the right to asylum and to a nationality. Prominent among these expressed ideals was the right to a shared family life,13 irrespective of national boundaries.14

Family reunification doctrine is based on the humanitarian right to marry and found a family life. Relatives of a legal migrant, whether they became kin before or after the migrants' move, should be allowed to join him or her in the new country of residence. Insisting on the family as the core unit of society, family reunification doctrine gives the family precedence even over the nation state, which is charged to maintain the family's integrity. If any element in international humanitarian doctrine trumps the individual's right to family life, however, it is the "best interests of the child." Spelled out most clearly in the various articles of the Convention on the Rights of the Child, these measures bestow on children, regardless of their nationality or whereabouts, the right to the care and company of a family: most specifically to the care and company of both parents, if possible, whether defined

8 See, for example, http://www.europeum.org/doc/pdf/855.pdf.

9 See Bledsoe (2004).

10 http://www.ohchr.org/english/law/cmw.htm

11 http://www.unicef.org/crc/

12 For a summary of this history, see http://www.ohchr.org/english/about/publications/docs/fs2.htm.

13 See, e.g., http://www.hrea.org/learn/guides/family.html and (Jastram, 2003).

14 The EU "Proposal for a Council Directive on the Right to Family Reunification" spells out two additional principles, declaring family reunification necessary to the successful integration of third-country nationals residing lawfully in EU member states and a way to stabilize and deepen the roots of immigrants, enabling them to lead a "normal family life" (COM/99/0638 final - CNS 99/0258, at http://eur-

lex.europa.eu/smartapi/cgi/sga doc?smartapil.celexapilprod!CELEXnumdoc\&lg=EN\&numdoc=51999PC0638\&model= guichett) 
biologically or by formal adoption. The duty of the state where an unaccompanied child appears is thus to reunite him/her with the family. If the family cannot be found or is deemed unsuitable, the state itself is bound to become the guardian in order to constitute the parent to which the Convention on the Rights of the Child declares that a child is entitled.

\section{Family reunification in practice}

Despite the best of intentions from which human rights efforts have arisen, they have spawned considerable debate. Disputes have centered on the tensions between individual vs. collective rights; the insistence on universal standards to the detriment of local practices; the financial hardship that upholding the conventions may impose on countries; and the morality of what some argue is an essentially Western patriarchal ideology.15 Further, there is considerable slippage between signature and practice. The various human rights bills and instruments themselves carry different legal weight. Covenants, statutes, protocols and conventions are considered legally binding for their signatory states. By contrast, declarations, principles, and guidelines, though they provide implementation guidance to states and have a moral force, carry no binding legal effect.16 With their varying histories, resources, and geographical positions, states may ignore or adhere selectively to the principles they have agreed to uphold, or attach conditions to them that are difficult to meet. Equally significant in shaping compliance with human rights laws and conventions is that while the original instruments laid out broad principles, each signatory is expected to implement and enforce them through its own governance structures and its civil codes, a fact that produces enormous variation in interpretation and standards. Spain, for example, enacts international human rights and family reunification measures through its seventeen Autonomous Communities, whose administrative structures themselves differ in how they interpret and implement the rules.

Immigrants themselves have further concerns. Bringing anyone at all to a distant place can be a daunting financial and legal proposition, especially for citizens of from poor countries. The costs alone are enormous, not just for transportation but for middlemen, translators, lawyers, and the like. Immigrants worry further about encountering belligerent immigration officials, and about themselves being deported if they try to bring others in ways the host country deems illicit. The fact that the costs and legal risks for coming to and re-entering a country are spiraling places increasing value on whatever rules or attributes will protect freedom of movement. One of the key challenges they face in bringing family members to Europe is the state's powers to define what, precisely, a family is and who belongs to it. European family reunification laws extend to only a narrow range of relationships that people from many countries would call "family." Most countries mark the boundary between childhood and adulthood chronologically, usually age 18, stipulating a minimum of 18 for bringing a spouse and less than 18 for a child.17 Further restrictions govern number of partners.18 European countries are monogamous by law, and their family reunification policies follow suit. Excluded is a second wife, meaning that only one wife at a time from a polygynous household can have a social security card, a health card, and a residence permit. As well, EU pressures to exclude are shrinking

15 E.g., Wallerstein (1995), Sarat and Kearns, eds. (1996), Scott (1996), Mutua (2002), and Shweder et al, eds. (2002). See Merry (2005) and Ticktin (2006) for examples of an important critical domain in anthropology on human rights and humanitarianism.

16 http://www.ohchr.org/english/law. See also Schabas (1996), Watson (1999), Sanford (2003).

17 Efforts to protect girls against early marriage are part of the intent in banning the reunification of wives younger than

18. See especially the UN High Commission on Refugees, http://www.unhchr.ch/html/menu3/b/64.htm.

18 Though France used to allow multiple spouses to immigrants, Pasqua laws banned this possibility. See, for example, http://www.worldpress.org/europe/0402lemonde.htm; Sargent and Cordell (2003). 
qualifications for family reunification to a core of highly circumscribed ties with tight age windows and few allowable variations in sexual preference and marital status. Conjugal unions are increasingly policed to rule out what host countries see as immigration convenience (e.g., De Hart, 2006), and non-EU citizens applying for entry to join a spouse in many European countries are now held to standards of emotional attachment that few of their citizens could meet (see Fleischer, ms.).

Further struggles arise over who, exactly, is a parent and who is a child. Most European countries follow the Convention on the Rights of the Child, defining immigrant childhood in temporal and dependency terms: an unmarried dependent below 18.19 They may deny reunification claims, however, for children suspected to be victims of trafficking or those whose parents who cannot meet state standards of stable employment or adequate income or accommodation, declaring their parents or guardians to be inappropriate caretakers. Excluded as well are any foster children who a legal migrant has not adopted according to legal procedures that the host country recognizes. When the aim is to exclude, however, the state may reduce childhood to a biological condition, deploying new technologies that become available for measuring the composition of bodily matter. According to Empez (pers. comm.), Spanish authorities who encounter newly arrived unaccompanied Moroccan youth routinely take them to the hospital for bone density scans, less to ensure their welfare than to identify individuals who can be sent back. The state may also challenge biological or legal claims to parenthood, and demand parents provide DNA evidence.20 Even the temporal boundaries childhood may be redefined. Expressing concerns about problems of integrating older children, Germany is moving toward reducing the age of children's eligibility for reunification to 12.21

The state itself, then, if it is trying to exclude, selectively seizes on the language humanitarian doctrine as a weapon to reject immigration claims. At the same time, families themselves may use reunification rules to try to select members for immigration based on the chances that their attributes can qualify them for entry in a destination country. Mexican women actually try to create children who U.S. immigration law will recognize as citizens and who can eventually bring them and the rest of the family in family reunification. The right to citizenship by virtue of birth on U.S. soil that is inscribed in constitutional law, the Fourteenth Amendment, gives a child full citizenship, including, once he/she reaches 18 , the right to bring other family members to the U.S. as legal residents. With U.S. citizenship at such a global premium and other means of entering closing rapidly, place of birth has become a heavily commoditized attribute for the children of women from geographically proximate Mexico. Each year, many pregnant Mexican women try to reach the U.S. to select their children into the population of U.S. born babies, whether by undertaking dangerous desert and river crossings or by scheduling a caesarean section during a three-day visa stay.22

\section{Conceptualizing family reunification practice: selecting commoditized attributes}

To grasp the emerging dynamics surrounding humanitarian doctrine and the family reunification policies it generates, we draw on three concepts. First is Marilyn Strathern's (1988) notion of the "partible self," which sees personal identity as a collection of socially significant single attributes.

19 Spain is generous in this rule compared, for example, to Germany, which now allows only children below age 12 to come in family reunification, unless the entire family comes at once or the parents are highly skilled (http://www.migrationinformation.org/Feature/display.cfm?ID=51).

20 E.g., http://www.washingtonpost.com/wp-dyn/content/article/2007/09/20/AR2007092002620.html and Hartman (2006).

21 http://www.migration-info.de/migration und bevoelkerung/artikel/030304.htm

22 "A different kind of border cross." Chicago Tribune, April 30, 2003. 
Examples of such attributes may include gender, height, residence locale, family name, or skin color anything can be isolated out. These attributes, however, are implicitly relational, defined with respect to other people; even the quality of being single implicitly draws attention to a negative relational attribute. As microcosms of relations, individual attributes comprise social nodes from which further transactions can be initiated. The notion of the partible self has particular utility when joined to a second notion, that of commodification. Partible entities that become commodified are dissociated from their original context and declared universally exchangeable goods, allowing them to be produced in mass quantity and placed on the commercial market for sale to the highest bidder (e.g., Appadurai, 1986). Commodification can bring benefit. Possessing an attribute of value relative to an external group may qualify an individual for special loans or training. At the same time, even the most highly personal attribute, if it has commodity value in the external world, may become the object of exchanges over which the possessor has little control. A woman, for example, is said to be vulnerable to exploitation through the commodification of her sexual attributes, separating them from the total bundle of her emotions and ties, and placing her at the disposal of the commercial sex trade (eg., Gates, 1996; Sharp, 2000).

The notion of the self as a set of partible facets that can be commodified for gain finds ready application in family reunification policy. Immigration legislation builds on the idea of a partitioned self, whether this describes particular job skills or a nationality that is subject to political persecution elsewhere. In so far as they build on attributes of a partitioned self, family reunification rules even take on commoditized values that surpass those of the individuals who possess them. What we underscore for the case of family reunion is the demand that personal characteristics, increasingly limited in scope, explicitly demand a relationship to someone else. Only, that is, a relationship, often requiring documentation, to a specified other person can be converted to transactable immigration value. Further, the attributes targeted for conversion in family reunification take on value only when converted across a national boundary, in a place to which the possessor does not belong. Such a relationship is defined further by quantity. While the position of "child" can be plural, having multiple simultaneous holders, positions such as "spouse" are mutually exclusive. Limited to a singular holder, they effectively comprise a "slot" that just one person at a time can occupy, though multiple people can circulate through it over time. Finally, the legal bases on which family members are reunited are different, and they only connect family members to an individual migrant: not to one another. members of a single family have different grounds of legitimacy. In our view, state efforts to intensify compliance with to such potentially restrictive and contradictory family reunification requirements themselves form the fault lines along which families splits may occur.

The idea of a self composed of potentially commoditized attributes is a useful way to frame family reunification for social science analysis. The problem is that the configuration so far implies hegemony in social transactions, minimizing the role of individual action and intent. Outcomes such as those we have encountered are not easily attributed to Foucault's vision of "governmentality" (1979), the complex politics through which states exact discipline less by force than by subjecting individuals to minute surveillance and judgment, effectively enrolling individuals themselves, through "technologies of the self," to enforce them. Notions of "resistance" and even "unintended consequences" fall equally short. Studying social practice, however, inevitably which requires a notion of agency, and that surrounding family reunification is no different. To retain the idea of an attributedefined group, we draw on what we call "acts of selection" (Bledsoe, 2004). Combining the idea of selection from statistics (e.g., Heckman and Smith, 1995) with agency perspectives from the social sciences, this notion posits that actors may try to select themselves, however fleetingly, into or out of pathways of probability on the basis of attributes that would link them to a particular population. Individuals seeking to shape the future, that is, may do so less by responding to the past from within 
their current membership in a group than by emphasizing those characteristics that would qualify them as members of new groups, based on their prediction of the opportunities that membership in these groups may entail.23 Applied to family reunification, that is, individuals may try to select themselves - or others -- into groups where immigration advantage may be best obtained. The cases described here thus point to social formations that assemble around the inner perimeters of allowable categories of particular populations, populations into which actors have selected themselves, whether through movement or through the use of language.

\section{Generating forms of transnational African family life in Europe}

The above discussion has attempted to distill out several principles that guide the application of family reunification policy. Most cases, however, are complex mixes of labeling, application, and response in which ultimate cause would be impossible to discover. What is important for here is that actors on all sides - individuals, families, states -- engage in immigration struggles that increasingly turn on the international language of family reunification. In what follows, we describe three cases of African groups attempting to come to Europe and the permutations of family reunification action that ensue.

\section{The best interests of the child: unaccompanied Moroccan minors}

Empez' work on Moroccan boys who manage to cross the Straits of Gibralter in speedboats or under trucks that board ferry boats from Tangier shows that the use of humanitarian language of the "best interests of the child" and the "competent parent" in family reunification transactions is complex indeed. According to her observations, these follow precisely the lines of humanitarian rules.

Further, all actors - the state as well as boys and their parents - draw on these idioms in their struggle over whether boys who manage to arrive may stay or must be sent back to Morocco.

As legitimate means for adults to enter Europe disappear, the fact that unaccompanied children may gain legal residence in Spain if the state's Child Protection System has been their guardian for at least nine months leads many Moroccan youth, feeling the weight of family responsibility, to try to be unaccompanied minors (Empez and Galea Montero, 2005). To do so, they must meet the allowable categories for child entry along specific age lines. While individuals 18 and over can be labeled illegal adults and deported, the state can also send back children under 16 automatically, on the grounds that they are too young to have made a key life decision such as migration, and that it is acting in their best interests in sending them home. Anticipating such strictures, most Moroccan boys begin trying to come at exactly 16, the age that would allow them to be wards of the Spanish state for nine months. The cases of boys from 16 to 17 and 3 months become complex arenas of construal on all sides. As Empez shows, when Spanish authorities first contact them to report they have their sons, Moroccan parents, through the advice of NGOs and lawyers, use the humanitarian language against themselves, trying to define themselves as "incompetent" by humanitarian standards. Claiming they cannot care for children properly or even that they are abusive, parents hope to oblige Spain state to take on the role of legal guardian to their sons.24 Most important, Spanish officials use the language of humanitarianism to "reunite" as many Moroccan boys with their families as possible (ms.). They do this knowing that the boys, upon their return, will likely be met by police who beat them, load them

23 See Johnson-Hanks (2007) for a seminal analysis of intentionality in demographic action.

24 Empez' dissertation work in Tangier (ms.) shows also that Spanish immigration policies have altered socialization practices in northern Morocco. Increasingly impoverished by EU policies of exclusion, Moroccan families are trying to produce children specifically for export to Europe. 
on to buses, and deposit them in the desert far to the south -- and that those who return to their impoverished families may be spurned as failures.

\section{The law of monogamy: Cameroonians in Germany and Gambians in Spain}

The cases of Cameroonians in Germany and of Gambians in Spain shed very different light on family reunification dynamics. Looking at two groups with very different educational and employment profiles, and from two different African countries, we examine the impact of the logic of spousal singularity in the wake of recent efforts to tighten immigration rules in two different European countries.

In the severe constraints of the present German labor market, Cameroonians who try to come to Germany by lodging asylum applications and through student visas find that almost the only way to stay, as non-OECD citizens, and earn money is to merge their family life directly with that of host country citizens: to marry or reproduce a German citizen. The very different pathways open to women and women, however, illustrate family reunification's highly divisive outcome among members of the same nationality.

Cameroonian women who stay in Germany are often those who gained residence rights by bearing a child by a German man who is willing to recognize it officially, irrespective of any longterm paternal obligations. Using German Federal Statistical Office figures on the children of unmarried parents, Fleischer (ms.) found that in 2004, although there were about twice as many Cameroonian men as women in Germany many more were born to a Cameroonian woman than to a Cameroonian man: 240 versus 92, respectively. Among married partners, just 49 children born to parents who were both Cameroonian but 165 children born to a Cameroonian and German conjugal pair. Again, there were considerably more, proportionately, children born to a Cameroonian/German marriage who were born to Cameroonian women and their German husbands, than to Cameroonian men and their German wives (84 and 81, respectively).

For Cameroonian men, the pathway to legal residence in Germany family is entirely different. Most German women who strike up relationships with Cameroonian men are substantially older than their partners, and are unwilling or unable to have a child. As well, the likelihood of becoming the parent of a German child independently of its mother is almost out of the question for a Cameroonian man. Claiming residency by producing a German child is thus much rarer for a man than for a woman from Cameroon. For a Cameroonian man without a job, the best route to staying is through contracting and sustaining a marriage to a German woman for at least three years, after which he can obtain residence, although authorities continue to exert surveillance, and may investigate cases of divorce after three years.25 Fleischer found that in 2004, there were 163 binational marriages between a Cameroonian and a German in Germany - most of them Cameroonian men marrying German women - but just six marriages between Cameroonian men and women. The further complexity is that many Cameroonian men desire children and want to return home eventually. Confronted with the logic of singularity on which family reunification rules of marriage rest, some men quietly retain a marriage with a woman back home by whom they have borne children, or ask their families to find a wife who they can visit periodically before their final return.26 Because a Cameroonian man may

25 After two years a foreign spouse of a German citizen can apply for residency independent of the spouse; after three years he/she receives temporary residence and can apply for permanent residency.

26 These practices bear some resemblance to forms of serial monogamy described in Africa most often as a wealthy man marrying several women over time or a young man trying out several unions before defining one as a marriage (see, e.g., 
come to see marriage to a German woman as a temporary necessity and look to Cameroon for his main family future, he may come to see "traditional" - or at least Cameroonian -- marriage the base, and "formal" marriage in the West as the temporary distortion.

Efforts by Cameroonians in Germany to acquire a German partner and bear German children become telling evidence of how sharply Germany has reduced its modes of entry. Not surprisingly, many marriages between Cameroonian men and German women are troubled, and the German fathers of Cameroonian women's children are often a fleeting presence.27 Cameroonian immigrants in Germany now orient their reproductive and marital and reproductive lives in Germany more toward Germans than toward their compatriots.

\section{Gambians in Spain}

The case of Gambians in Spain highlights a very different outcome that the law of monogamy can impose on an immigrant group: one in which children and their parents can be separated. This pattern, we believe, stems from the family reunification premise of the "child" position as one of plurality versus that of the "spouse" as one of a single, one-at-a-time partner.28

The number of registered Gambians in Spain is small: just 14,425, according to the 2006 Municipal Register. But Gambians pose an important case in several respects. Despite their modest numbers, they are the Sub-Saharan group that has tried the longest to make a working life possible in postFranco Spain. Gambians first arrived in the late 1960's on a labor contract, and their numbers rose slowly as they found positions in the growing Spanish economy. Like other immigrants from the developing world, Gambians encounter increasing financial and legal obstacles to bringing family members. Unlike most groups, however, many Gambians maintain close ties to rural areas of a high fertility polygynous homeland. Most importantly, Gambian nationals have what appears to be the highest fertility rate by far for any group in Spain: 3.57 in 2005, compared to the 2005 fertility rate for all of Spain: around 1.4.

Given Gambians' marginality, together with tightening state enforcement efforts and increasing costs of bringing each person, a family reunification position in Spain is valuable indeed. Once created, it is likely to remain filled quite independently of the original occupant. Gambians are caught, however, between the family reunification principles encoded in Spanish law. A legally resident man can bring all the children that he or his legal wife can claim as their own; given the health and educational advantages of being in Spain, children are likely to remain. However, he can bring another wife only if she displaces the previous holder of the position, obliging her to move out or become a kind of domestic servant in the household. Where the number of children can legally accumulate, the number of legal wives is fixed. For immigrants from countries with polygynous practices, a slot dynamic can result: a tendency to rotate multiple holders through a single position.

Comaroff and Roberts, 1977, on southern Africa). In this case, however, a Cameroonian man seeking to resume a reproductive life back home must circulate, in both time and space, through a legally monogamous marriage. Further, the German wife in such a marriage, often older than her husband, may well have come from a previous union, and hence she is technically doing the same thing.

27 Luraschi (2007) reports that in Italy, however, the structure of immigration policies allows Cameroonians to marry and partner with each other.

28 We draw here on Bledsoe, Houle, and Sow (2006), an analysis of Gambian fertility and territorial settlement in Spain, and on Bledsoe (2006) on the effects of family reunification on Gambian families. 
Spanish family reunification policies appear to have three peculiar demographic effects on Gambian families. First, they generate a population of women who are married at younger ages than back in the African homeland itself. Second, they produce a circulating pool of fertile young women from Africa who experience high rates of reproduction for short slices of time, replacing as they replace older wives and are eventually replaced themselves. Finally, they induce families to accumulate children but to substitute older wives for younger ones. Whether a wife leaves at her wishes or despite her resistance and whether she remains in the household, beyond the edges of the official records, or leaves Spain altogether, each time the marriage cycle shifts, we lose track of one individual in the fertility denominator. In the case of Gambians, the observed demographic result may be either an overstated numerator in the form of an accumulation of children of the same man by more than one wife, or an understated denominator in the form of an unreported wife. The result of the resulting turnover among women through the singular wife slot and the accumulation of children who remain in Spain independently of their mothers, is a high fertility rate for the Gambian population as a synthetic whole. While many Gambian women in Spain do have many children, therefore, the number is likely inflated relative to the number of women who could have borne them.

The fact that the law banning polygamy trumps the right of the child to live with both parents transforms more routine patterns of circulation common to the homeland into more sharply bifurcated pathways in Europe. This puts older women at risk of exclusion and isolation, and sets parents and their children onto independent trajectories from one another.29 Such things happen, we stress, less just because of "traditional" norms of polygyny but because the wife slot becomes a pathway to bring young women to Spain. The fact that a man can have plural but not plural wives also creates new patterns, leading men in some instances to select wives for migration to Spain who look like children because they are more likely to get in, claiming they are their children. Creating a very young age at marriage in Spain, family reunification policies compel Gambians to look more "traditional," a pattern that conforms more to older "African" patterns than to those of today.

\section{Conclusion}

This paper has argued that the press toward exclusion in Europe is reducing family reunification to one of the few remaining windows of transnational mobility for people from poor regions. As it does so, it creates incentives to offer up for speculation those relationships or pieces of a partible self with the greatest transactable human rights value across a national boundary, according to foreign civil laws. With an increasing migration premium on those characteristics with certain family reunification value, the results are predictable. As the potential holders of family reunification positions try to follow the rigid letter of the law underlying the separate legalities of their positions, their pathways as members of a family will almost certainly veer from one another.

Sub-Saharan Africa itself, to be sure, has complex practices of child fostering and rotating wives through a household as they age. Of interest here are two things. One is the claims that human rights doctrine makes for itself, to bring family members together in the new context, and to protect children from early marriage and support their rights to the company of their parents. The other is the unintended and even nefarious results that claims based on these ideologies can generate. As one of the great humanitarian legacies of the twentieth century, human rights initiatives were hardly intended to become weapons. And EU countries hardly set out to create immigrant populations with

29 See Azoulay and Quiminal (2002) and Sargent and Cordell (2003) on Malian women who come to Paris for marriage. 
early marriage, high fertility, rotating marital partners, and large proportions of single mothers. But no principles stand on their own as self-contained, autonomous forces. Even measures created with the most benevolent of intents can have perverse effects. When family reunification and the special rights conferred on children become the means of last resort to reach a destination, a migration premium will inevitably be placed on people who can be construed as children and close relatives. The same criteria that were established to reunite families become the lines on which individuals will likely be excluded or exploited, not just by governments but by families themselves, undermining the very forms of family integrity that human rights doctrine claims to safeguard.

Few would argue that some immigrants trying to come to Spain are using human rights and family reunification provisions in ways that smack of manipulation of the social categories that Western culture holds as most vulnerable and sacred. Not only are certain people likely to be delegated to make the move on the basis of their age and relationship; age and relationship may be adjusted socially to qualify a person for residential legitimacy. The line of response to this charge that this paper has presented would point out that people needing to ensure the wellbeing of their families must try to fit into whatever categories are available and that hardening the legal lines intensifies the need to maneuver around them precisely along the separate logics that underlie these positions. And yet we also emphasize that Europeans themselves are not held to the terms of a formal marriage contract or a parental relationship to justify their presence: most especially not to the highly conservative models of being a wife or a child that family reunification policies increasingly stipulate.30 People from wealthy countries are allowed to move to Spain with no pretense at all to a family relationship. The more that Europe tries to seal out, the more those who seek legitimacy must appear to conform to the most rarified, archaic - if not mythical - family models of the European past.31

What does all this suggest for human rights? Even the most well-intended instruments can be turned to weapons of restriction rather than to inclusion. The context, not any autonomous force inherent in the rules themselves, determines how a particular rule structure will be used. With so much at stake on the boundaries of family reunification categories, immigration possibilities are reduced to what only the international humanitarian doctrine has preserved and to ever-tighter gender- and agespecific boundaries within it. If this assessment is correct, not only have the categorical boundaries of family reunification have become an immigration battleground; forces of exclusion will undoubtedly lead to more maneuvering, not less, around children and reproduction, and by myriad national, international, and family players.

\footnotetext{
30 Like the rest of Europe, Spain has seen the advent of informal unions and a rising age at first marriage for women in recent decades. In 2003 the average age at first marriage for women was 27.8 (http:/ / epp.eurostat.ec.europa.eu/cache/ITY OFFPUB/KS-EH-06-001/EN/KS-EH-06-001-EN.PDF). 31 For parallel observations, see Raissiguier (2003). For an example of the biological model that parallels such reductionisms, see: http:/ www.nytimes.com/2007/04/10/us/10dna.html?pagewanted=2\&ei=5087\%0A\&em\&en=5ed0cee42cb1ef5c\&ex $=1$ $\underline{176350400}$
} 


\section{Bibliography}

Appadurai, Arjun. 1986. "Introduction: commodities and the politics of value." (IN)The Social Life of Things: Commodities in Cultural Perspective. New York: Cambridge University Press. Pp.3-63.

Azoulay, Muriel and Catherine Quiminal. 2002. «Reconstruction des rapports de genre en situation migratoire. Femmes réveillées, hommes menacés en milieu soninké, »VEI Enjeux Rapports de sexe, rapports de genre, domination et emancipation 128: 87-102.

Bertrand, Bissuel. 2002. “Divorce or else...” Le Monde (liberal), Paris, France, Feb. 11.

Bledsoe, Caroline H. 2004a. "Acts of selection: reproduction and risk in contemporary America." Conference on The Political and Symbolic Implications of Quantification. Working Group on Anthropology and Population. Watson Institute for International Studies, Brown University.

Bledsoe, Caroline H. 2004b. "Reproduction at the margins: migration and legitimacy in the New Europe." Demographic Research, Special Collection 3. Pp. 85-116.

Bledsoe, Caroline H., René Houle, and Papa Sow. 2007. "High fertility Gambians in low fertility Spain: The dynamics of child accumulation across transnational space." Demographic Research 16:375412.

Cabré, Anna. 1999. El Sistema Català de Rreproducció. Barcelona: Proa.

Calavita, Kitty. 2005. Immigrants at the Margins: Law, Race, and Exclusion in Southern Europe. Cambridge: Cambridge University Press.

Cole, Jennifer and Deborah Durham, eds. 2006. Generations and Globalization: Youth, Age, and Family in the New World Economy. Bloomington, Indiana: Indiana University Press.

Coleman, David A. 1994. "Fertility and immigration among immigrant populations as measures of integration." Journal of Biosocial Sciences 26(1):107-136.

Comaroff, John L. and Simon Roberts. 1977. "Marriage and extra-marital sexuality: the dialectics of legal change among the Kgatla," Journal of African Law 21:97-123.

Dahinden, Janine. 2005. "Contesting transnationalism? Lessons from the study of Albanian migration networks from former Yugoslavia.” Global Networks 5(2):191-208.

De Hart, Betty. 2006. "Introduction: The marriage of convenience in European immigration law." European Journal of Migration and Law 8(3-4): 251-262.

Domingo i Valls, Andreu, Jaume Clapés Estrada, and Maria Prats Ferret. 1995. Condicions de Vida de la Població d'Origen Africa i Llatinoamerica a la Regió Metropolitana de Barcelona: Una Aproximación Qualitativa. Barcelona: Institut d'Estudis Metropolitans de Barcelona y Diputació de Barcelona. 
Domingo i Valls, Andreu, Jordi Bayona i Carrasco, Inés Brancós i Coll. 2002. Migracions Internacionals $i$ Poblacio Jove de Nacionalitat Estrangera a Catalunya. Barcelona: Generalitat de Catalunya, Departament de la Presidencia, Secretaria General de Joventut. No. 7.

Domingo i Valls, Andreu and René Houle. 2005. "The economic activity of immigrants in Spain: between complementarity and exclusion." Paper for the International Union for the Scientific Study of Population. 25th International Population Conference. Tours, France. July 18-23.

Domingo I Valls, Andreu and Inés Brancós. 1996. “Aspectes demogràfics de la immigració estranjera a les comarques barcelonines.” Papers de Demografia, 116, Barcelona: Universitat Autònoma de Barcelona, Centre d'Estudis Demogràfics.

Empez, Nuria. 2007. "Social construction of neglect: the case of unaccompanied minors from Morocco to Spain.” Max Planck Institute for Demographic Research. WP-2007-007.

Empez, Nuria and Vicens Galea Montero. 2005. "Family strategies and unaccompanied migrant minors." Paper for the European Association of Population Studies, Working Group on the Anthropological Demography of Europe. Max Planck Institute for Demographic Research. Rostock, Germany.

Farjas i Bonet, Anna. 2002. El Procés Migratori Gambià a Comarques Gironines: El Cas de Banyoles, Olot $i$ Salt. Doctoral Thesis presented at the Departament de Pedagogia, Universitat de Girona.

Fleischer, Annett. In process. PhD Dissertation, Free University of Berlin.

Foucault, Michel. 1979b. "Governmentality." Ideology and Consciousness 6:5-21.

Gates, Hill. 1996. "Buying brides in China - again.” Anthropology Today 12(4):8-11.

Ginsburg, Faye D. and Rayna Rapp, eds. 1995. Conceiving the New World Order: The Global Politics of Reproduction. Berkeley: University of California Press.

Glick, Schiller Nina, Linda Basch, Cristina Blanc-Szanton. 1995. "From immigrant to transmigrant: theorizing transnational migration." Anthropology Quarterly 68(1): 48-63.

Hannerz, Ulf. 1996. Transnational Connections: Culture, People, Places. London: Routledge.

Heckman, James J. and Jeffrey A. Smith. 1995. "Assessing the case for social experiments." Journal of Economic Perspectives 9(2):85-110.

Hochschild, Arlie. 2000. "The nanny chain." The American Prospect 11(4).

Hogart, Keith and Cristóbal Mendoza. 2000. "African immigrant workers in Spanish agriculture." Working Paper No. 2, Center for Comparative Immigration Studies. La Jolla, CA.

Hondagneu-Sotelo, Pierrette. 1995. "Women and children first: new directions in anti-immigrant policy," Socialist Review 25(1): 169-190. 
Hondagneu-Sotelo, Pierrette. 2002. "Families on the Frontier: From braceros in the fields to braceras in the home," (IN) Latinos: Remaking America. Marcelo Suarez-Orozco, ed. Cambridge, MA: Harvard University Press. Pp. 259-273.

Inda, Jonathan Xavier. 2002. "Biopower, reproduction, and the migrant woman's body," (IN) Decolonial Voices: Chicana and Chicano Cultural Studies in the 21st Century. Arturo J. Aldama and Naomi Quiñonez, eds. Bloomington: Indiana University Press. pp. 98-112.

Jastram, Kate. 2003. "Family unity: the new geography of family life," Migration Information Source. Migration Policy Institute. May 1, 2003.

http://www.migrationinformation.org/Feature/display.cfm?ID=118.

Johnson-Hanks, Jennifer. 2006. An Uncertain Honor: Modern Motherhood in an African Crisis. Chicago: University of Chicago Press.

Kaplan Marcusán, Adriana. 1998. De Senegambia a Cataluña: Procesos de Aculturación e Integración Social. Barcelona: Fundación "la Caixa."

Kaplan Marcusán, Adriana. Ms. "Procesos migratorios, transformaciones culturales e identitarias: Senegambianos en Cataluña.”

Kulu, Hill. 2005. "Migration and fertility: competing hypotheses re-examined," European Journal of Population 21(1):51-87.

Lesthaeghe, Ron J. 2006.“The second demographic transition in the United States: exception or textbook example?” Population and Development Review 32(4): 669-698.

Lesthaeghe, Ron, Dirk van de Kaa.1986."Twee demografische transities?” (IN) Bevolking -Groei en Krimp. Special Issue of Mens en Maatschappij. Ron Lesthaeghe, Dirk van de Kaa, eds. Deventer: Van Loghum Slaterus. Pp. 9-24.

Levitt, Peggy. 2001. The Transnational Villagers. Berkeley: University of California Press.

Levitt, Peggy and Nina Glick Schiller. 2004. "Conceptualizing simultaneity: A transnational social field perspective on society.” International Migration Review 38 (3):1002-39.

Luraschi, Moira. 2007. "New family ties in a diaspora context: the case of Cameroonian migration in Italy." University of Turin: Italy.

Merry, Sally Engel. 2005. "Human rights and global legal pluralism: reciprocity and disjuncture." (IN) Mobile People, Mobile Law: Expanding Legal Relations in a Contracting World. Franz von Benda Beckman, Keebet von Benda Beckman, Anne Griffiths, eds. Ashgate. Pp. 215-233.

Mutua, Makau. 2002. Human Rights: A Political and Cultural Critique. Philadelphia: University of Pennsylvania Press.

Ong, Aihwa. 2002. "The Pacific shuttle: families, citizenship, and capital circuits." (IN) The Anthropology of Globalization: A Reader. Jonathan Xavier Inda and Renato Rosaldo, eds. Malden, MA: Blackwell. Pp. 172-197. 
Quiminal, Catherine. 1993. «Mode de constitution des ménages polygames et vécu de la polygamie en France », Migrations Études 41.

Raissiguier, Catherine. 2003. "Troubling mothers: immigrant women from Africa in France." Jenda: $A$ Journal of Culture and African Women Studies 4.

Rodríguez García, Dan. 2001. "Inmigración africana hacia Europa: ¿Un proceso sin fin? El caso de Gambia,” Ô Willaeri (La cooperació). Barcelona: ETANE, especial 10ª Diada Cultural Afrocatalana. 1. Pp.5-7.

Rodríguez García, Dan. 2004. Inmigración y Mestizaje Hoy: Formación de Matrimonios Mixtos y Familias Transnacionales de Población Africana en Cataluña. Bellaterra: Universitat Autònoma de Barcelona, Servei de Publicacions.

Roig Vila, Marta and Teresa Castro Martín. 2007. "Immigrant mothers, Spanish babies: childbearing patterns of foreign women in Spain” WP-17. Bilbao: Fundación BBVA.

Sanford, Victoria. 2003. Buried Secrets: Truth and Human Rights in Guatemala. New York: Palgrave Macmillan.

Sarat, Austin and Thomas R. Kearns, eds. 1995. Identities, Politics and Rights. Ann Arbor: University of Michigan Press.

Sargent, Carolyn and Dennis Cordell. 2003. "Polygamy, disrupted reproduction, and the state: Malian migrants in Paris, France," Social Science and Medicine 56(9):1961-72.

Sargent, Carolyn and Stéphanie Larchanché-Kim. 2006. "Liminal lives: immigration status, gender, and the construction of identities among Malian migrants in Paris." American Behavioral Scientist 50(1):Pp.9-26.

Schabas, William A. 1996. The Death Penalty as Cruel Treatment and Torture: Capital Punishment Challenged in the World's Courts. Boston: Northeastern University Press.

Scott, Joan W. 1996. Only Paradoxes to Offer: French Feminists and the Rights of Man. Cambridge: Harvard University Press.

Sharp, Leslie. 2000. "The commodification of the body and its parts." Annual Review of Anthropology 29:287-328.

Shweder, Richard A., Martha Minow, and Hazel Rose Markus, eds. 2002. Engaging Cultural Differences: The Multicultural Challenge in Liberal Democracies. New York: Russell Sage Foundation Press.

Sow, Papa. 2004a. "Prácticas comerciales transnacionales y espacios de acción de los senegaleses in España," (IN) Migración y Desarrollo Estudios sobre Remesas y Otros Prácticas Transnacionales en España.

Natalia Ribas, Ángeles Ecrivá, eds. Córdoba: Consejo Superior de Investigaciones Científicas, Instituto de Estudios Sociales Avanzados. Pp. 235-254. 
Sow, Papa. 2004b. "Mujeres inmigrantes y/o esposas de inmigrantes senegaleses y gambianos en Cataluña (España): entre la vida familiar y la vida professional," Doc. Anàl. Geogr. 43, Pp. 69-88.

Strathern, Marilyn. 1988. The Gender of the Gift: Problems with Women and Problems with Society in Melanesia. Berkeley: University of California Press.

Ticktin, Miriam. 2006. "Where ethics and politics meet: The violence of humanitarianism in France." American Ethnologist 33(1):33-49.

United Nations. 2000. "Replacement migration: is it a solution to declining and ageing population?" United Nations Department of Economic and Social Affairs, Population Division, United Nations. New York. The UN High Commission on Refugees, http://www.unhchr.ch/html/menu3/b/64.htm.

Vertovec, Steven. 2001. "Transnationalism and identity," Journal of Ethnic and Migration Studies 27(4):573-83.

Wallerstein, Immanuel. 1995. "The insurmountable contradictions of liberalism: human rights and the rights of peoples in the geoculture of the modern world-system." South Atlantic Quarterly 94(4):116179 .

Watson, James Shand. 1999. Theory and Reality in the International Protection of Human Rights. Ardsley, NY: Transnational Publishers. 